\title{
MXenes@Te as a composite material for high-performance aluminum batteries
}

\author{
Xiaogeng Huo ${ }^{1}$, Xiaoxu Wang ${ }^{2}$, Jianling $\mathrm{Li}^{1 *}$, Bao Zhang ${ }^{1}$, Yu Zhang ${ }^{1}$, Te Qin ${ }^{1}$ and Feiyu Kang
}

\begin{abstract}
The emerging two-dimensional (2D) materials, MXenes, play an important role in various fields of energy storage and exhibit excellent electrochemical performance. Herein, we prepared few-layered MXenes $\left(\mathrm{F}-\mathrm{Ti}_{3} \mathrm{C}_{2} \mathrm{~T}_{x}\right)$ and loaded Te on the surface of $\mathrm{F}_{-}-\mathrm{Ti}_{3} \mathrm{C}_{2} \mathrm{~T}_{x}$ by using a simple hightemperature evaporation method. In addition, the electrochemical performance of the aluminum battery with $\mathrm{F}-\mathrm{Ti}_{3} \mathrm{C}_{2} \mathrm{~T}_{x}$ as support material was studied. The initial charge/discharge specific capacities are $987 / 1096 \mathrm{~mA} \mathrm{~h} \mathrm{~g}^{-1}$ at $0.2 \mathrm{Ag}^{-1}$. An obvious discharge voltage plateau of about $1.3 \mathrm{~V}$ appears at various current densities. The specific capacity is about $258 \mathrm{~mA} \mathrm{~h} \mathrm{~g}^{-1}$ with MXenes@Te as the active material in the aluminum battery, which benefits from the excellent electronic conductivity of the MXenes and their 2D layered structure. Density functional theory calculations were carried out to explore the mechanism. $\mathrm{Ti}_{3} \mathrm{C}_{2} \mathrm{O}_{2} @ \mathrm{Te}$ is more inclined to adsorb $\left[\mathrm{AlCl}_{4}\right]^{-}$than $\mathrm{Ti}_{3} \mathrm{C}_{2} \mathrm{O}_{2}$. Furthermore, the valence change behavior of element Te was studied by using thermodynamic calculation (FactSage 7.1). X-ray photoelectron spectroscopy results show that when the battery is fully charged to $2.4 \mathrm{~V}$ element $\mathrm{Te}$ and $\mathrm{Ti}$ ions $\left(\mathrm{Ti}^{3+}, \mathrm{Ti}^{2+}\right)$ are oxidized to $\mathrm{Te}^{4+}$ and $\mathrm{Ti}^{4+}$. In contrast to the charging process, the high-valence $\mathrm{Te}^{4+}$ and $\mathrm{Ti}^{4+}$ are reduced again during discharging. Element $\mathrm{Te}$ is reduced to lower-valence $\mathrm{Te}^{2-}$ when the discharge voltage is lower than $0.6 \mathrm{~V}$, and a higher charge voltage $(2.56 \mathrm{~V})$ is required for Te to be oxidized to $\mathrm{Te}^{6+}$.
\end{abstract}

Keywords: MXenes@Te, aluminum batteries, specific capacity, density functional theory

\section{INTRODUCTION}

The excessive use of fossil fuels has had a significant impact on the environment on which humans depend, which is why researchers around the world have become interested in emerging clean energy [1]. At present, many kinds of emerging energy sources exist, such as solar energy, geothermal energy, hydro energy, wind energy, ocean energy, and chemical energy. However, some problems still need to be addressed regarding the reversible storage and use of energy [2]. With the high reserves (up to $8 \%$ ), low cost, high safety, and high specific capacity of aluminum, the research on the emerging aluminum battery system has become one of the important directions for energy storage [3]. In recent years, aluminum batteries based on cathode materials, such as carbon materials [4-8], oxides [9-13], sulfides [14-17], and selenides [18] have been found to exhibit excellent electrochemical performance under normal temperature conditions. However, some challenges remain for the development of aluminum batteries compared with lithium-ion batteries, which is mainly limited by the electrochemical properties of positive electrode materials, such as low capacity and poor cyclic performance [19]. Therefore, finding positive electrode materials with superior electrochemical performance or developing novel aluminum batteries is the key in this field. A rechargeable aluminum-sulfur battery was first reported by Gao et al. [20], which demonstrated a capacity of $1000 \mathrm{~mA} \mathrm{~h} \mathrm{~g}^{-1}$ for over 20 cycles. In addition, the charge/discharge mechanism was described, and sulfide $\mathrm{Al}_{3} \mathrm{~S}_{2}$ was formed during the charge/discharge processes. Subsequently, Yu et al. [21] proposed a rechargeable aluminum-sulfur battery under normal temperature conditions and discussed its charge/discharge mechanism. Similar to lithium-sulfur batteries and sodium-sulfur batteries, a series of polysulfides and sulfides were formed during the charge/discharge processes in aluminum-sulfur batteries. In recent years, aluminum-selenium batteries have also been extensively studied, which deliver excellent electrochemical performance and high discharge voltages of about $1.5 \mathrm{~V}[22,23]$. Most recently, Jiao et al. [24] constructed a rechargeable aluminum battery with an initial reversible capacity of $913 \mathrm{~mA} \mathrm{~h} \mathrm{~g}$, which showed excellent electrochemical performance. Subsequently, a tellurium (Te) nanowire positive electrode was prepared to construct a novel tellurium-aluminum battery, and it delivered an ultra-high discharge capacity of $1026 \mathrm{~mA} \mathrm{~h} \mathrm{~g}^{-1}$ at $0.5 \mathrm{Ag}^{-1}$ [25]. The construction of the novel aluminum-tellurium battery has greatly improved the electrochemical performance of aluminum batteries and injects fresh blood into their development. However, few reports have been focused on aluminum-tellurium batteries, and their energy storage mechanism is unclear. The process of inhibiting the shuttle effect of multiple tellurides in particular is cumbersome. Therefore, finding a new host material and studying its compatibility with Te and its electrochemical performance in aluminum batteries are among the research focuses in this field. MXenes are a novel family of two-dimensional (2D) materials first discovered by Gogotsi and co-workers [26,27]. It can be defined with the structural formula of $\mathrm{M}_{n+1} \mathrm{X}_{n} \mathrm{~T}_{x}$, where $\mathrm{M}$ is a

\footnotetext{
${ }^{1}$ State Key Laboratory of Advanced Metallurgy, School of Metallurgical and Ecological Engineering, University of Science and Technology Beijing, Beijing 100083, China

2 Beijing computing center, Beijing Academy of Science and Technology, Beijing 100094, China

${ }^{3}$ Laboratory of Advanced Materials, School of Materials Science and Engineering, Tsinghua University, Beijing 100084, China

* Corresponding author (email: lijianling@ustb.edu.cn)
} 
transition metal ( $\mathrm{Ti}, \mathrm{V}, \mathrm{Cr}, \mathrm{Zr}, \mathrm{Hf}, \mathrm{Nb}, \mathrm{Mo}, \mathrm{Ta}$, and $\mathrm{W}), \mathrm{X}$ is carbon and/or nitrogen, $\mathrm{T}_{x}$ is the terminated functional groups $(\mathrm{OH}, \mathrm{Cl}$ or $\mathrm{F})$, and $n$ is an integer typically between 1 and 3 [28]. MXenes have numerous kinds of properties (electronic, band gap, layered structure, thermal, and mechanical properties) that play important roles in different fields, especially in energy storage [29,30], such as supercapacitors [31-33], lithium-ion batteries [34-37], sodium-ion batteries [38-41], magnesium-ion batteries [42,43], and lithium-sulfur batteries [44,45]. The lithium-sulfur batteries show excellent electrochemical performance, which benefits from the excellent electronic conductivity of MXenes and their 2D layered structure [46]. Few reports have been made on the application of MXenes in aluminum batteries. In 2017 [47], a rechargeable aluminum battery based on $\left(\mathrm{V}_{2} \mathrm{CT}_{x}\right)$ MXenes cathode was reported. The battery's cycling performance is poor, and the cause of the battery capacity decline is still unclear. Subsequently, our laboratory studied the application of MXenes in aluminum batteries and explored their charge/discharge mechanism [48-50]. However, their electrochemical performance in aluminum batteries needs to be improved. Modifying MXenes or combining them with other high-capacity electrode materials is the most effective way to improve its electrochemical performance.

Herein, we used a simple high-temperature evaporation method to load Te on the surface of few-layered MXenes ( $F$ $\mathrm{Ti}_{3} \mathrm{C}_{2} \mathrm{~T}_{x}$ ). The scheme of the preparation is shown in Fig. 1. The microstructure and physicochemical properties of the materials were studied by X-ray diffraction (XRD), thermogravimetric analysis (TGA), scanning electron microscopy (SEM), and transmission electron microscopy (TEM). In addition, the electrochemical performance of the aluminum battery with MXene as the support material was studied, which exhibited excellent rate performance and cyclic stability. Furthermore, density functional theory (DFT) calculations were performed to explore the mechanism, and the valence change behaviors of $\mathrm{Te}$ and $\mathrm{Ti}$ ions were studied by thermodynamic calculation (FactSage 7.1) and X-ray photoelectron spectroscopy (XPS).

\section{RESULTS AND DISCUSSION}

As shown in Fig. 2a, the pattern of $\mathrm{Ti}_{3} \mathrm{AlC}_{2}$ (purchased from 11 Tech.) shows two distinct characteristic peaks (002) and (104). After etching with HF acid, the peak (104) completely disappeared, and the peak (002) moved from $9.52^{\circ}$ to $8.98^{\circ}$, even lower angles, which indicated that $\mathrm{Al}$ was removed by $\mathrm{HF}$ acid, and the $2 \mathrm{D} \mathrm{Ti}_{3} \mathrm{C}_{2} \mathrm{~T}_{x}$ was prepared [51]. Furthermore, the prepared $\mathrm{Ti}_{3} \mathrm{C}_{2} \mathrm{~T}_{x}$ was ultrasonically stripped in ethanol, and the peak (002) moved from $8.98^{\circ}$ to $7.08^{\circ}$ (Fig. 2a), indicating that the lattice spacing of the peak (002) increased [52]. Fig. $2 b$ shows the XRD patterns of $\mathrm{Ti}_{3} \mathrm{C}_{2} \mathrm{~T}_{x}$ and $\mathrm{F}-\mathrm{Ti}_{3} \mathrm{C}_{2} \mathrm{~T}_{x} @ \mathrm{Te}$. The electrode materials $\mathrm{Ti}_{3} \mathrm{C}_{2} \mathrm{~T}_{x} @ \mathrm{Te}$ and $\mathrm{F}-\mathrm{Ti}_{3} \mathrm{C}_{2} \mathrm{~T}_{x} @ \mathrm{Te}$ show obvious characteristic peaks of Te, indicating that a large amount of Te is loaded on the surface of the materials [45]. As shown in Fig. 2c, $\mathrm{d}$, the XPS spectra of $\mathrm{Ti} 2 \mathrm{p}$ in $\mathrm{F}_{-} \mathrm{Ti}_{3} \mathrm{C}_{2} \mathrm{~T}_{x}$ and $\mathrm{F}-\mathrm{Ti}_{3} \mathrm{C}_{2} \mathrm{~T}_{x} @ \mathrm{Te}$ indicate that the $\mathrm{Ti}$ bonds on the surface of $\mathrm{F}-\mathrm{Ti}_{3} \mathrm{C}_{2} \mathrm{~T}_{x}$ changed after Te loading. During the process of Te loading, low-valence $\mathrm{Ti}$ ions were oxidized to higher-valence $\mathrm{Ti}^{4+}$, which improved the stability of $\mathrm{F}_{-} \mathrm{Ti}_{3} \mathrm{C}_{2} \mathrm{~T}_{x} @ \mathrm{Te}$ [48]. Fig. 2e shows the $\mathrm{N}_{2}$ adsorption/desorption isotherm plots of $\mathrm{Ti}_{3} \mathrm{C}_{2} \mathrm{~T}_{x}$ and $\mathrm{F}-\mathrm{Ti}_{3} \mathrm{C}_{2} \mathrm{~T}_{x}$. The specific surface areas of $\mathrm{Ti}_{3} \mathrm{C}_{2} \mathrm{~T}_{x}$ and $\mathrm{F}-\mathrm{Ti}_{3} \mathrm{C}_{2} \mathrm{~T}_{x}$ are 11.5 and $32.7 \mathrm{~m}^{2} \mathrm{~g}^{-1}$, respectively. Fig. $2 \mathrm{f}$ shows the pore size distributions of $\mathrm{Ti}_{3} \mathrm{C}_{2} \mathrm{~T}_{x}$ and $\mathrm{F}-\mathrm{Ti}_{3} \mathrm{C}_{2} \mathrm{~T}_{x}$. Some micropores with a size of $3.5 \mathrm{~nm}$ appear in $\mathrm{F}_{-} \mathrm{Ti}_{3} \mathrm{C}_{2} \mathrm{~T}_{x}$. The specific surface area changes from 11.5 to $32.7 \mathrm{~m}^{2} \mathrm{~g}^{-1}$, and some micropores appear inside $\mathrm{F}_{-} \mathrm{Ti}_{3} \mathrm{C}_{2} \mathrm{~T}_{x}$. As shown in Fig. 2g, $\mathrm{Ti}_{3} \mathrm{C}_{2} \mathrm{~T}_{x} @ \mathrm{Te}$ presents a strong endothermic peak at $500-650^{\circ} \mathrm{C}$ with the peak temperature around $620^{\circ} \mathrm{C}$, and the mass percentage of $\mathrm{Te}$ is approximately $49.8 \%$. As shown in Fig. 2h, $\mathrm{F}_{-} \mathrm{Ti}_{3} \mathrm{C}_{2} \mathrm{~T}_{x} @ \mathrm{Te}$ also shows a strong endothermic peak at $500-650^{\circ} \mathrm{C}$. However, its peak temperature drops slightly to about $608^{\circ} \mathrm{C}$, indicating that Te escapes from F$\mathrm{Ti}_{3} \mathrm{C}_{2} \mathrm{~T}_{x} @ \mathrm{Te}$ more easily. In addition, the TGA curve (Fig. 2h) still shows a downward trend between $650^{\circ} \mathrm{C}-800^{\circ} \mathrm{C}$, which may be due to some Te entering the mesopores of the MXenes during the high-temperature evaporation process, and the mass ratio of Te is about $57.3 \%$. Physicochemical characterizations show that the MXenes@Te composite was successfully prepared, and the MXenes loaded more elemental Te after stripping.

The microscopic morphology of the materials was further characterized by SEM and TEM. The $\mathrm{Ti}_{3} \mathrm{AlC}_{2}$ shows a $3 \mathrm{D}$ block structure (Fig. 3a) before etching. The $\mathrm{Ti}_{3} \mathrm{C}_{2} \mathrm{~T}_{x}$ exhibits a uniform $2 \mathrm{D}$ layered structure after etching by $\mathrm{HF}$ acid, and the thickness of one single layer is less than $1 \mathrm{~nm}$ (Fig. 3b, c). The Al in $\mathrm{Ti}_{3} \mathrm{AlC}_{2}$ is selectively removed by $\mathrm{HF}$ acid. After the $\mathrm{Al}$ atomic layer is lost, the $3 \mathrm{D}$ (MAX) material $\mathrm{Ti}_{3} \mathrm{AlC}_{2}$ is transformed into the $2 \mathrm{D}$ (MXene) material $\mathrm{Ti}_{3} \mathrm{C}_{2} \mathrm{~T}_{x}$. The atomic structure before and after etching is shown in Fig. S1. The SEM image of F$\mathrm{Ti}_{3} \mathrm{C}_{2} \mathrm{~T}_{x}$ is shown in Fig. $3 \mathrm{~d}$, and the multilayered $\mathrm{Ti}_{3} \mathrm{C}_{2} \mathrm{~T}_{x}$ changed into $\mathrm{F}-\mathrm{Ti}_{3} \mathrm{C}_{2} \mathrm{~T}_{x}$ after stripping. The specific surface area of $\mathrm{F}_{-} \mathrm{Ti}_{3} \mathrm{C}_{2} \mathrm{~T}_{x}$ becomes larger as shown in the microscopic perspective, which is consistent with the $\mathrm{N}_{2}$ desorption/adsorption tests (Fig. 2c). Fig. 3e shows the TEM image of $\mathrm{Ti}_{3} \mathrm{C}_{2} \mathrm{~T}_{x}$. The microstructure of $\mathrm{Ti}_{3} \mathrm{C}_{2} \mathrm{~T}_{x}$ is $2 \mathrm{D}$ with multilayer stacking, and each single layer is composed of many thinner layer stacks.

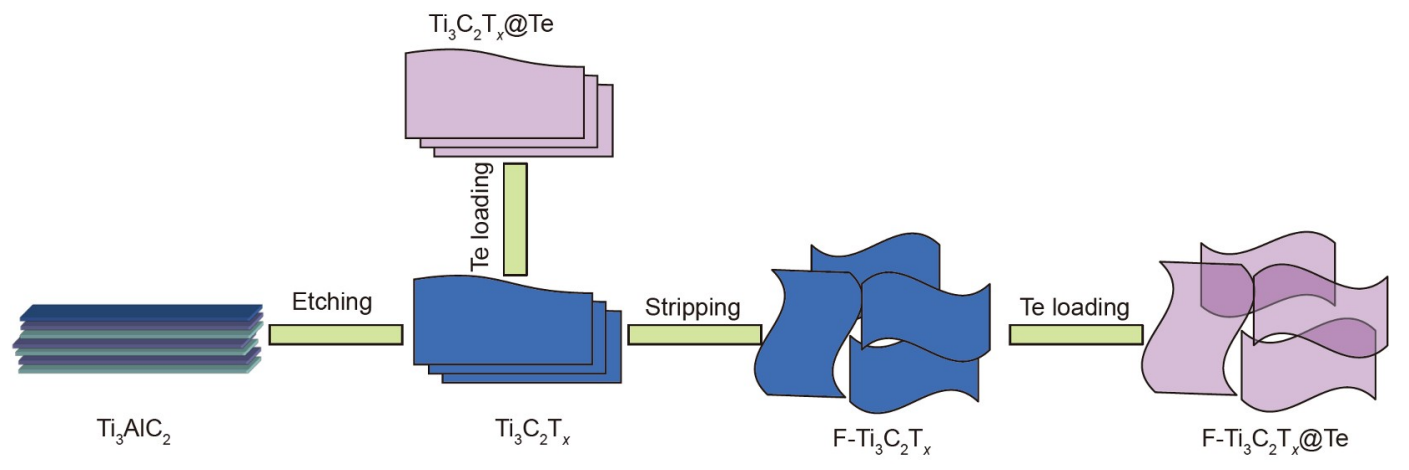

Figure 1 Schematic illustration of the synthesis of MXenes@Te. 

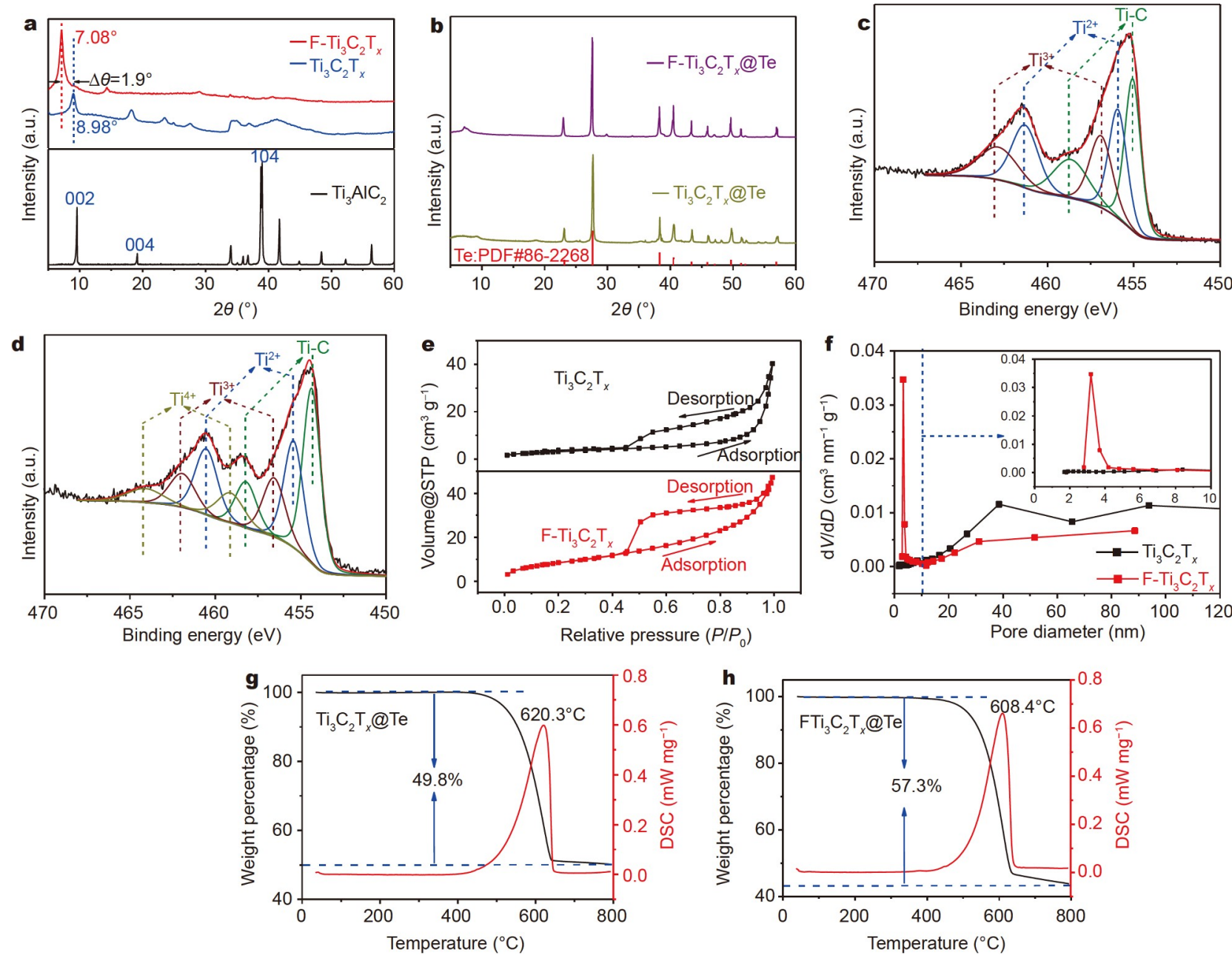

Figure 2 XRD patterns of (a) $\mathrm{Ti}_{3} \mathrm{AlC}_{2}, \mathrm{Ti}_{3} \mathrm{C}_{2} \mathrm{~T}_{x}$ and $\mathrm{F}-\mathrm{Ti}_{3} \mathrm{C}_{2} \mathrm{~T}_{x}$, (b) $\mathrm{Ti}_{3} \mathrm{C}_{2} \mathrm{~T}_{x} @ \mathrm{Te}$ and $\mathrm{F}_{-} \mathrm{Ti}_{3} \mathrm{C}_{2} \mathrm{~T}_{x} @ \mathrm{Te}$. (c, d) XPS spectra of Ti $2 \mathrm{p}$ in $\mathrm{F}-\mathrm{Ti}_{3} \mathrm{C}_{2} \mathrm{~T}_{x}$ and $\mathrm{F}$ $\mathrm{Ti}_{3} \mathrm{C}_{2} \mathrm{~T}_{x} @ \mathrm{Te}$. (e) $\mathrm{N}_{2}$ adsorption/desorption isotherm plots of $\mathrm{Ti}_{3} \mathrm{C}_{2} \mathrm{~T}_{x}$ and $\mathrm{F}-\mathrm{Ti}_{3} \mathrm{C}_{2} \mathrm{~T}_{x}$. (f) The micropore size distributions of $\mathrm{Ti}_{3} \mathrm{C}_{2} \mathrm{~T}_{x}$ and $\mathrm{F}-\mathrm{Ti}_{3} \mathrm{C}_{2} \mathrm{~T}_{x}, \mathrm{calculat}_{3}$ with the Barrett-Joyner-Halenda (BJH) method. TGA profiles of (g) $\mathrm{Ti}_{3} \mathrm{C}_{2} \mathrm{~T}_{x} @ \mathrm{Te}$ and (h) F- $\mathrm{Ti}_{3} \mathrm{C}_{2} \mathrm{~T}_{x} @ \mathrm{Te}$.

Fig. 3f shows the TEM image of $\mathrm{F}-\mathrm{Ti}_{3} \mathrm{C}_{2} \mathrm{~T}_{x}$, which presents a sheet structure with a size of about $500 \mathrm{~nm}$. Fig. $3 \mathrm{~g}$ shows the SEM image of $\mathrm{Ti}_{3} \mathrm{C}_{2} \mathrm{~T}_{x} @ \mathrm{Te}$, and Te is adsorbed on the surface and the interlayer of $\mathrm{Ti}_{3} \mathrm{C}_{2} \mathrm{~T}_{x}$. The $\mathrm{Ti}_{3} \mathrm{C}_{2} \mathrm{~T}_{x} @ \mathrm{Te}$ presents a 3D block structure, and the introduction of Te blocks the channels between the layers of $\mathrm{Ti}_{3} \mathrm{C}_{2} \mathrm{~T}_{x}$. In Fig. 3h, the SEM image of F$\mathrm{Ti}_{3} \mathrm{C}_{2} \mathrm{~T}_{x} @ \mathrm{Te}$ shows that $\mathrm{Te}$ is uniformly adsorbed on the surface of $\mathrm{F}-\mathrm{Ti}_{3} \mathrm{C}_{2} \mathrm{~T}_{x}$. Therefore, effective delamination is essential to the Te loading, thereby avoiding the agglomeration of $\mathrm{Te}$ on the surface of $\mathrm{F}_{-} \mathrm{Ti}_{3} \mathrm{C}_{2} \mathrm{~T}_{x}$ [53]. Fig. $3 \mathrm{i}$ shows the energy-dispersive $\mathrm{X}$ ray spectrometer (EDS) surface scans of $\mathrm{F}-\mathrm{Ti}_{3} \mathrm{C}_{2} \mathrm{~T}_{x} @ \mathrm{Te}$, which is mainly composed of $\mathrm{C}, \mathrm{Ti}$, and $\mathrm{Te}$ elements. Fig. $\mathrm{S} 2$ shows the EDS spectrum of $\mathrm{F}_{-} \mathrm{Ti}_{3} \mathrm{C}_{2} \mathrm{~T}_{x} @ \mathrm{Te}$, which is mainly composed of $\mathrm{C}, \mathrm{Ti}$, and $\mathrm{Te}$ elements, and a small amount of $\mathrm{O}$ and $\mathrm{F}$ elements come from the functional groups on the surface [54]. The EDS surface scans of $\mathrm{Ti}_{3} \mathrm{C}_{2} \mathrm{~T}_{x} @ \mathrm{Te}$ are shown in Fig. S3. According to the characterization of SEM and TEM, effective delamination is important for Te loading, and the Te loading on $\mathrm{F}-\mathrm{Ti}_{3} \mathrm{C}_{2} \mathrm{~T}_{x}$ surface is more uniform.

Subsequently, the electrochemical performances of $\mathrm{Ti}_{3} \mathrm{C}_{2} \mathrm{~T}_{x} @ \mathrm{Te}$ and $\mathrm{F}-\mathrm{Ti}_{3} \mathrm{C}_{2} \mathrm{~T}_{x} @ \mathrm{Te}$ were studied in aluminum batteries. Fig. S4 shows the electrochemical performance of
$\mathrm{Ti}_{3} \mathrm{C}_{2} \mathrm{~T}_{x} @ \mathrm{Te}$ in aluminum batteries. Fig. S4a shows the cyclic voltammetry (CV) curve with a scan rate of $0.5 \mathrm{mV} \mathrm{s}^{-1}$ and a scan range of $0.01-2.4 \mathrm{~V}$. The open circuit voltage of the aluminum battery is about $1.5 \mathrm{~V}$. Obvious cathode peaks are around $0.5,2.0$, and $2.2 \mathrm{~V}$, and obvious anode peaks are located around $1.3,1.0$, and $0.4 \mathrm{~V}$. Fig. S4b shows the charge/discharge curves at different current densities, consistent with the CV curves. When the current density is $0.2 \mathrm{Ag}^{-1}$, the charge specific capacity is $1121 \mathrm{~mA} \mathrm{hg}^{-1}$ (Te as the active material), and the discharge specific capacity is $1186 \mathrm{~mA} \mathrm{~h} \mathrm{~g}^{-1}$. When the current densities are set to $0.4,0.6,0.8,1.0$, and $1.5 \mathrm{Ag}^{-1}$, the discharge specific capacities are $446,375,304,239$, and $212 \mathrm{~mA} \mathrm{~h} \mathrm{~g}^{-1}$, respectively. As shown in Fig. S4c, the charge/discharge capacities gradually decrease in steps when the current density increases from small to large. The discharge specific capacity is about $200 \mathrm{~mA} \mathrm{~h} \mathrm{~g}^{-1}$ at a current density of $1.5 \mathrm{Ag}^{-1}$, indicating an excellent rate performance. Fig. S4d shows the cycling performance, and the discharge specific capacity is $275 \mathrm{~mA} \mathrm{~h} \mathrm{~g}^{-1}$ with a current density of $0.6 \mathrm{~A} \mathrm{~g}^{-1}$ after 150 cycles. The coulombic efficiency is close to $100 \%$ during the cycle. However, the capacity retention rate is only about $45 \%$ because the multilayered $\mathrm{Ti}_{3} \mathrm{C}_{2} \mathrm{~T}_{x}$ causes the reunion of the loaded $\mathrm{Te}$ [55]. Therefore, the cyclic stability 

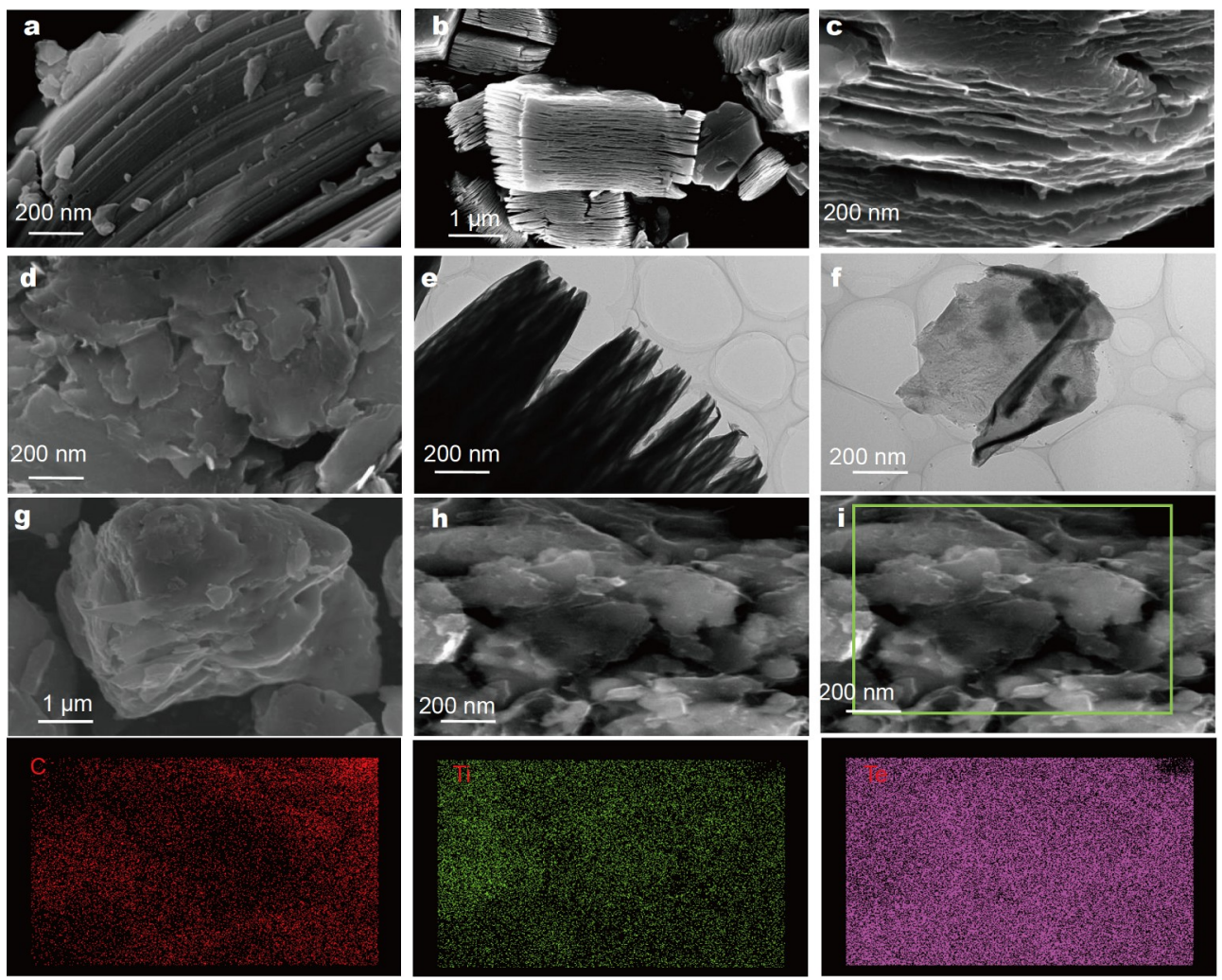

Figure 3 SEM and TEM images of the samples. SEM images of (a) $\mathrm{Ti}_{3} \mathrm{AlC}_{2}$, (b, c) $\mathrm{Ti}_{3} \mathrm{C}_{2} \mathrm{~T}_{x}$, (d) $\mathrm{F}_{-}-\mathrm{Ti}_{3} \mathrm{C}_{2} \mathrm{~T}_{x} ; \mathrm{TEM}$ images of (e) $\mathrm{Ti}_{3} \mathrm{C}_{2} \mathrm{~T}_{x}$, (f) F-Ti $\mathrm{T}_{3} \mathrm{C}_{2} \mathrm{~T}_{x} ; \mathrm{SEM}$ images of $(\mathrm{g}) \mathrm{Ti}_{3} \mathrm{C}_{2} \mathrm{~T}_{x} @ \mathrm{Te}$ and $(\mathrm{h}) \mathrm{F}-\mathrm{Ti}_{3} \mathrm{C}_{2} \mathrm{~T}_{x} @ \mathrm{Te}$; (i) selected scan area of $\mathrm{F}-\mathrm{Ti}_{3} \mathrm{C}_{2} \mathrm{~T}_{x} @ \mathrm{Te}$.

needs to be improved.

Fig. 4 shows the electrochemical performance of the aluminum battery with $\mathrm{F}_{-} \mathrm{Ti}_{3} \mathrm{C}_{2} \mathrm{~T}_{x}$ as the support material. Fig. 4a presents the CV curves with a scan rate of $0.5 \mathrm{mV} \mathrm{s}^{-1}$ and a scan range of $0.01-2.4 \mathrm{~V}$. To better explain the redox reaction, we conducted two cycles of CV test on the battery. The CV curves are almost the same with obvious cathode peaks around $0.5,1.0$, $1.4,2.0$, and $2.3 \mathrm{~V}$ and obvious anode peaks around 1.3, 1.0, 0.8, and $0.4 \mathrm{~V}$. We conducted a CV test with a tantalum sheet as the cathode and an aluminum sheet as the anode to prove its stability in aluminum batteries. The test results reveal that it does not undergo a strong oxidation reaction under high voltage $(2.4 \mathrm{~V})$ conditions. Fig. $4 \mathrm{~b}$ shows the initial and second charge/ discharge curves, and the inset is the curve of the voltage versus time during the charge/discharge processes. The initial charge specific capacity is $987 \mathrm{mAh} \mathrm{g}^{-1}$, and the discharge specific capacity is $1096 \mathrm{~mA} \mathrm{hg}^{-1}$. Two charge platforms are present around 2.0 and $2.3 \mathrm{~V}$ when charged from the open circuit voltage $(1.4 \mathrm{~V})$ first, and two discharge platforms are present around 1.3 and $1.0 \mathrm{~V}$ during discharging. In addition, two short discharge platforms appear around 0.8 and $0.5 \mathrm{~V}$. The charge specific capacity for the second cycle is $1377 \mathrm{~mA} \mathrm{~h} \mathrm{~g}^{-1}$, and the discharge specific capacity is $1365 \mathrm{~mA} \mathrm{~h} \mathrm{~g}^{-1}$. The charge curve shows three small charge platforms at about $0.5,1.0$, and $1.3 \mathrm{~V}$. The discharge voltage platform is slightly higher than that of the initial value, and the charge/discharge specific capacities are higher than the initial ones, probably because the initial charge starts from the open circuit voltage $(1.4 \mathrm{~V})$, and Te is not sufficiently oxidized. Fig. $4 \mathrm{c}$, d show the charge/discharge curves and rate performance of the aluminum batteries under different current density conditions. As shown in Fig. 4d, when the current density increases from small to large, the charge/discharge capacities decrease in a stepwise manner. When the current is $1.5 \mathrm{~A} \mathrm{~g}^{-1}$, the specific capacity is about $400 \mathrm{~mA} \mathrm{~h} \mathrm{~g}^{-1}$, and when the current density is reset to $0.6 \mathrm{Ag}^{-1}$, the charge/discharge capacities show a steadily increasing trend in steps. Fig. 4e shows the cyclic stability of the aluminum battery. When the current density is $0.6 \mathrm{Ag}^{-1}$, the discharge specific capacity is $449 \mathrm{~mA} \mathrm{~h}$ $\mathrm{g}^{-1}$ after 150 cycles ( $\mathrm{Te}$ as the active material). The capacity retention rate is about $70 \%$, and the coulombic efficiency is close

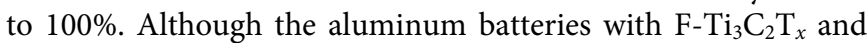
$\mathrm{F}-\mathrm{Ti}_{3} \mathrm{C}_{2} \mathrm{~T}_{x}$ as support materials are not inferior in terms of rate

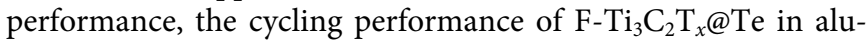
minum batteries is much better than that of $\mathrm{Ti}_{3} \mathrm{C}_{2} \mathrm{~T}_{x} @ \mathrm{Te}$ [53]. In addition, the cycling performance of $\mathrm{Ti}_{3} \mathrm{C}_{2} \mathrm{~T}_{x} @ \mathrm{Te}$ in aluminum battery is unstable due to the rearrangement of Te during the charge/discharge processes. Furthermore, we studied the selfdischarge behavior of $\mathrm{F}-\mathrm{Ti}_{3} \mathrm{C}_{2} \mathrm{~T}_{x} @ \mathrm{Te}$ in aluminum batteries and showed the charge/discharge curves after different cycles. As shown in Fig. 4f, the prepared new battery was charged to $2.4 \mathrm{~V}$ after $4 \mathrm{~h}$ of rest, and the voltage was instantly reduced from 2.4 to $1.57 \mathrm{~V}$ after charging. After $48 \mathrm{~h}$ of rest, the voltage of the aluminum battery almost did not change significantly, and the final voltage was slightly higher than the open circuit voltage $(1.4 \mathrm{~V})$. The above results clearly show that the electrode material is stable in the electrolyte without a strong self-discharge behavior. Fig. $4 \mathrm{~g}$ shows the charge/discharge curves after different cycles at a current density of $0.6 \mathrm{~A} \mathrm{~g}^{-1}$.

The electrochemical performances of $\mathrm{F}-\mathrm{Ti}_{3} \mathrm{C}_{2} \mathrm{~T}_{x}$ and Te were studied in aluminum batteries to distinguish the capacities 

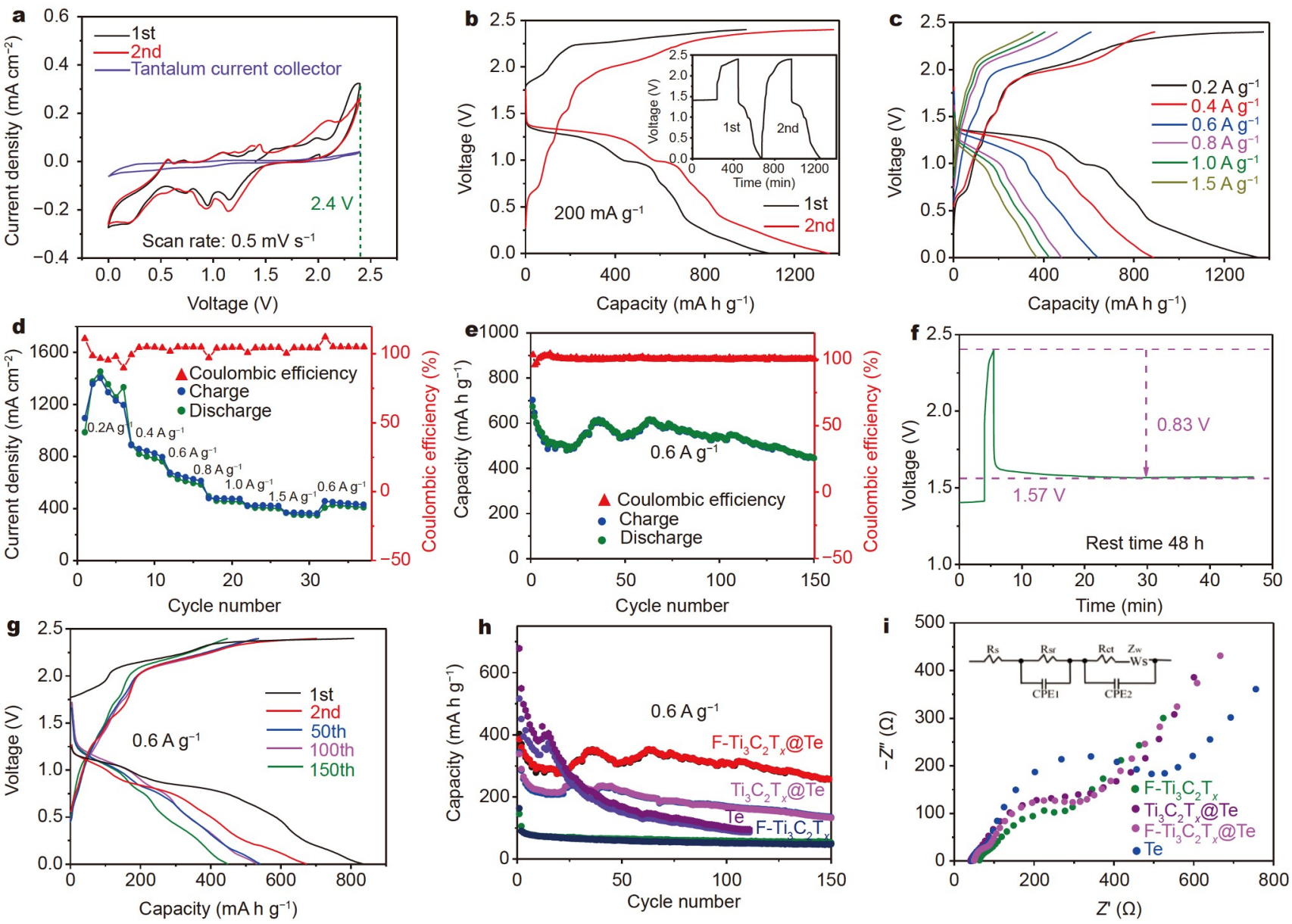

Figure 4 (a) CV curves of $\mathrm{F}-\mathrm{Ti}_{3} \mathrm{C}_{2} \mathrm{~T}_{x} @ \mathrm{Te}$. (b) Charge/discharge curves of $\mathrm{F}-\mathrm{Ti}_{3} \mathrm{C}_{2} \mathrm{~T}_{x} @ \mathrm{Te}$ at $0.2 \mathrm{Ag}^{-1}$. (c, d) Rate performance of $\mathrm{F}-\mathrm{Ti}_{3} \mathrm{C}_{2} \mathrm{~T}_{x} @ \mathrm{Te}$. (e) Cycling performance and coulombic efficiency of $\mathrm{F}_{-} \mathrm{Ti}_{3} \mathrm{C}_{2} \mathrm{~T}_{x} @ \mathrm{Te}$ at $0.6 \mathrm{Ag}^{-1}$. (f) Self-discharge behavior of the battery. (g) Charge/discharge curves of $\mathrm{F}-\mathrm{Ti}_{3} \mathrm{C}_{2} \mathrm{~T}_{x} @ \mathrm{Te}$ after different cycles. (h) Cycling performances of $\mathrm{F}_{-} \mathrm{Ti}_{3} \mathrm{C}_{2} \mathrm{~T}_{x}, \mathrm{Te}, \mathrm{Ti}_{3} \mathrm{C}_{2} \mathrm{~T}_{x} @ \mathrm{Te}$, and $\mathrm{F}_{-} \mathrm{Ti}_{3} \mathrm{C}_{2} \mathrm{~T}_{x} @ \mathrm{Te}$. (i) Alternative current (AC) impedance spectra of $\mathrm{F}$ $\mathrm{Ti}_{3} \mathrm{C}_{2} \mathrm{~T}_{x}, \mathrm{Te}, \mathrm{Ti}_{3} \mathrm{C}_{2} \mathrm{~T}_{x} @ \mathrm{Te}$, and F- $\mathrm{Ti}_{3} \mathrm{C}_{2} \mathrm{~T}_{x} @ \mathrm{Te}$.

provided by the support materials $\mathrm{F}-\mathrm{Ti}_{3} \mathrm{C}_{2} \mathrm{~T}_{x}$ and Te. Fig. S5 shows the electrochemical performance of $\mathrm{F}-\mathrm{Ti}_{3} \mathrm{C}_{2} \mathrm{~T}_{x}$ in aluminum batteries. As shown in Fig. S5a, the CV curve presents obvious anode peaks around 1.0 and $0.5 \mathrm{~V}$. Fig. S5b shows the initial and second charge/discharge curves, consistent with the $\mathrm{CV}$ curve. When the current density is $0.6 \mathrm{Ag} \mathrm{g}^{-1}$, the initial charge specific capacity is $153 \mathrm{~mA} \mathrm{~h} \mathrm{~g}^{-1}$, and the discharge specific capacity is $164 \mathrm{~mA} \mathrm{~h} \mathrm{~g}^{-1}$ with a discharge platform around $1.0 \mathrm{~V}$. The charge specific capacity for the second cycle is $113 \mathrm{~mA} \mathrm{~h}^{-1}$, and the discharge specific capacity is $89 \mathrm{~mA} \mathrm{~h}^{-1}$. Fig. $\mathrm{S} 5 \mathrm{c}$ shows the rate performance of $\mathrm{F}_{-} \mathrm{Ti}_{3} \mathrm{C}_{2} \mathrm{~T}_{x}$ in the aluminum battery. The specific capacity is about $30 \mathrm{mAh} \mathrm{g}^{-1}$ at $1.5 \mathrm{~A} \mathrm{~g}^{-1}$ and is approximately $50 \mathrm{~mA} \mathrm{~h} \mathrm{~g}^{-1}$ at the current density of $0.6 \mathrm{~A} \mathrm{~g}^{-1}$. Fig. S5d shows the cyclic stability. When the current density is $0.6 \mathrm{Ag}^{-1}$, the specific capacity is stable between 50 $60 \mathrm{~mA} \mathrm{~h} \mathrm{~g}^{-1}$ during 150 cycles. $\mathrm{F}-\mathrm{Ti}_{3} \mathrm{C}_{2} \mathrm{~T}_{x}$ shows excellent rate performance in aluminum batteries because of the good conductivity of MXenes. However, when the current density is set to $0.6 \mathrm{~A} \mathrm{~g}^{-1}$, the stable capacity provided by $\mathrm{F}-\mathrm{Ti}_{3} \mathrm{C}_{2} \mathrm{~T}_{x}$ in aluminum batteries is less than $60 \mathrm{~mA} \mathrm{hg}^{-1}$. Fig. S6 shows the electrochemical performance of Te in aluminum batteries, and Fig. S6a shows the CV curve for the initial and second cycles. Obvious cathode peaks are around $0.5,1.0$, and $2.3 \mathrm{~V}$, and a continuous anode peak is around $1.5 \mathrm{~V}$, which correspond to the charge/ discharge curves (Fig. S6b). The charge specific capacity of Te is $516 \mathrm{~mA} \mathrm{~h} \mathrm{~g}^{-1}$ in aluminum batteries, and the discharge specific capacity is $678 \mathrm{~mA} \mathrm{hg}^{-1}$ (current density of $0.6 \mathrm{Ag}^{-1}$ ). Fig. S6c shows the cyclic stability, and the specific capacity is $95 \mathrm{~mA} \mathrm{~h} \mathrm{~g}^{-1}$ after 110 cycles with a current density of $0.6 \mathrm{~A} \mathrm{~g}^{-1}$. The specific capacity of Te decays severely in the aluminum battery. Fig. $4 \mathrm{~h}$ shows the cyclic stabilities of $\mathrm{F}-\mathrm{Ti}_{3} \mathrm{C}_{2} \mathrm{~T}_{x}, \mathrm{Te}, \mathrm{Ti}_{3} \mathrm{C}_{2} \mathrm{~T}_{x} @ \mathrm{Te}$, and $\mathrm{F}-$ $\mathrm{Ti}_{3} \mathrm{C}_{2} \mathrm{~T}_{x} @ \mathrm{Te}$ in aluminum batteries. The aluminum battery with $\mathrm{F}_{-} \mathrm{Ti}_{3} \mathrm{C}_{2} \mathrm{~T}_{x} @ \mathrm{Te}$ as the cathode material has the best cyclic stability during 150 cycles at a current density of $0.6 \mathrm{~A} \mathrm{~g}^{-1}$, and the specific capacity is about $258 \mathrm{~mA} \mathrm{~h} \mathrm{~g}^{-1}$ after 150 cycles $\left(\mathrm{F}-\mathrm{Ti}_{3} \mathrm{C}_{2} \mathrm{~T}_{x} @ \mathrm{Te}\right.$ as the active material). Fig. 4i shows the impedance spectra of Te, F- $\mathrm{Ti}_{3} \mathrm{C}_{2} \mathrm{~T}_{x}, \mathrm{Ti}_{3} \mathrm{C}_{2} \mathrm{~T}_{x} @ \mathrm{Te}$, and F- $\mathrm{Ti}_{3} \mathrm{C}_{2} \mathrm{~T}_{x} @ \mathrm{Te}$ in aluminum batteries, respectively. Obviously, they are composed of two semi-circles (high-frequency region) and one upward sloping line (low-frequency region). The data obtained by fitting the equivalent circuit diagram (inset in Fig. 4i) are shown in Table S1. The Ohmic impedances $R_{s}$ of Te, $\mathrm{F}-\mathrm{Ti}_{3} \mathrm{C}_{2} \mathrm{~T}_{x}$, $\mathrm{Ti}_{3} \mathrm{C}_{2} \mathrm{~T}_{x} @ \mathrm{Te}$, and $\mathrm{F}-\mathrm{Ti}_{3} \mathrm{C}_{2} \mathrm{~T}_{x} @ \mathrm{Te}$ in aluminum batteries are about $50 \Omega$, which have no close relationship with the cathode materials. $R_{\mathrm{sf}}$ is the impedance of solid electrolyte interface (SEI) film at the interface of the electrode material, and $R_{\mathrm{ct}}$ is the charge 
transfer impedance. The charge transfer impedances $R_{\mathrm{ct}}$ of Te, F$\mathrm{Ti}_{3} \mathrm{C}_{2} \mathrm{~T}_{x}, \mathrm{Ti}_{3} \mathrm{C}_{2} \mathrm{~T}_{x} @ \mathrm{Te}$, and $\mathrm{F}-\mathrm{Ti}_{3} \mathrm{C}_{2} \mathrm{~T}_{x} @ \mathrm{Te}$ in aluminum batteries are $138,98,121$, and $102 \Omega$, respectively. The interface impedances $R_{\mathrm{sf}}$ of Te, F- $\mathrm{Ti}_{3} \mathrm{C}_{2} \mathrm{~T}_{x}, \mathrm{Ti}_{3} \mathrm{C}_{2} \mathrm{~T}_{x} @ \mathrm{Te}$, and $\mathrm{F}-\mathrm{Ti}_{3} \mathrm{C}_{2} \mathrm{~T}_{x} @ \mathrm{Te}$ in aluminum batteries are $432,176,326$, and $240 \Omega$, respectively. The fitted data show that the $R_{\mathrm{ct}}$ and $R_{\mathrm{sf}}$ of Te in aluminum batteries are high, which is determined by its nature of semiconducting. The $R_{\mathrm{ct}}$ and $R_{\mathrm{sf}}$ of $\mathrm{F}_{-} \mathrm{Ti}_{3} \mathrm{C}_{2} \mathrm{~T}_{x} @ \mathrm{Te}$ in aluminum batteries are 102 and $240 \Omega$, respectively. Compared with those of Te electrodes, they are significantly reduced, because MXenes have excellent electrical conductivity. In addition, the modified $\mathrm{F}-\mathrm{Ti}_{3} \mathrm{C}_{2} \mathrm{~T}_{x}$ contains more micropores, which can better promote the transfer of electrons and charges [56].

The Te element belongs to the oxygen group elements and exhibits different valence states $\left(\mathrm{Te}^{2-}, \mathrm{Te}^{2+}, \mathrm{Te}^{4+}\right.$, and $\left.\mathrm{Te}^{6+}\right)$ when oxidized or reduced. Herein, we studied the charge/discharge mechanism by using electrochemical methods, thermodynamic calculations (FactSage 7.1), and XPS characterization. Fig. 5a shows the CV curve of the aluminum battery with $\mathrm{F}-\mathrm{Ti}_{3} \mathrm{C}_{2} \mathrm{~T}_{x} @ \mathrm{Te}$ as the cathode material. The curve starts from the open circuit voltage of $1.4 \mathrm{~V}$; the pink curve is the initial cycle, and the green curve is part of the second cycle. The entire cycle process is divided into three parts: I, II, and III. The charge/discharge mechanism is shown in the following chemical equations. Equation (1) represents the chemical reaction occurring in part I, Equation (2) is the chemical reaction occurring in part II, and Equations ( 3 and 4 ) are the chemical reactions occurring in part III. All the above chemical reactions take place at the cathode of the aluminum battery. Equation (5) is the chemical reaction that takes place at the anode of the aluminum battery. Furthermore, we calculated the potentials $\left(v s . \mathrm{Al} / \mathrm{Al}^{3+}\right)$ when Te was oxidized or reduced to different valence states by using thermodynamic software (FactSage 7.1). The calculated results are shown in Table S2. When Te is reduced to $\mathrm{Te}^{2-}$, the potential is $0.65 \mathrm{~V}$. When $\mathrm{Te}$ is oxidized to $\mathrm{Te}^{2+}, \mathrm{Te}^{3+}, \mathrm{Te}^{4+}$, and $\mathrm{Te}^{6+}$, the potentials are $1.36,2.60,1.56$, and $2.57 \mathrm{~V}$, respectively. The potential is $1.76 \mathrm{~V}$ when $\mathrm{Te}^{2+}$ is oxidized to $\mathrm{TeCl}_{3}^{+}[24,25,57]$. Therefore, we conclude that $\mathrm{Te}$ is oxidized to $\mathrm{Te}^{2+}$ and $\mathrm{Te}^{4+}$ during the charge process of 1.4-2.4 V. The high-valence $\mathrm{Te}^{4+}$ is gradually reduced to Te in the discharge process of $2.4-0.01 \mathrm{~V}$, and Te is reduced to $\mathrm{Te}^{2-}$ as the voltage decreases.

Cathode:

I

$\mathrm{Te}+\left[\mathrm{AlCl}_{4}\right]^{-} \rightleftharpoons \mathrm{AlTeCl}+3 \mathrm{Cl}^{-}-2 \mathrm{e}^{-}$.

II

$\mathrm{Te}+2\left[\mathrm{AlCl}_{4}\right]^{-} \rightleftharpoons \mathrm{Te}\left(\mathrm{AlCl}_{4}\right)_{2}+2 \mathrm{e}^{-}$.

III

$\mathrm{Te}+4\left[\mathrm{AlCl}_{4}\right]^{-} \rightleftharpoons \mathrm{Te}\left(\mathrm{AlCl}_{4}\right)_{4}+4 \mathrm{e}^{-}$,

$\mathrm{Te}^{2+}+7\left[\mathrm{AlCl}_{4}\right]^{-} \rightleftharpoons 3\left[\mathrm{Al}_{2} \mathrm{Cl}_{7}\right]^{-}+\mathrm{TeCl}_{3} \cdot \mathrm{AlCl}_{4}+2 \mathrm{e}^{-}$.

Anode:

$4\left[\mathrm{Al}_{2} \mathrm{Cl}_{7}\right]^{-}+3 \mathrm{e}^{-} \rightleftharpoons \mathrm{Al}+7\left[\mathrm{AlCl}_{4}\right]^{-}$.

Fig. 5b shows the charge/discharge curves, and the charge/ discharge platforms $(2.2-2.4,1.4-1.2,1.2-0.9,0.9-0.3,0.5-1.1$, 1.1-1.5 and 1.5-2.2 V) marked in the curve correspond to the redox peaks of the CV curve. The specific capacity is $987 \mathrm{~mA} \mathrm{hg}^{-1}$ (the theoretical specific capacity of $\mathrm{Te}-\mathrm{Te}^{4+}$ is
844.2 $\mathrm{mA} \mathrm{h} \mathrm{g}^{-1}$ ) when the battery is charged from the open circuit voltage (approximately $1.4 \mathrm{~V}$ ) to $2.4 \mathrm{~V}$ at the current density of $0.2 \mathrm{~A} \mathrm{~g}^{-1}$. When the battery is discharged to $1.2,0.9$, and $0.3 \mathrm{~V}$ under the current density of $0.2 \mathrm{Ag}^{-1}$, the discharge specific capacities are 303,652 , and $756 \mathrm{~mA} \mathrm{~h}^{-1}$, respectively. When the battery is charged from 0.01 to $1.1,1.5$ and $2.2 \mathrm{~V}$ under the current density of $0.2 \mathrm{~A} \mathrm{~g}^{-1}$, the charge specific capacities are 100 , 170 , and $651 \mathrm{~mA} \mathrm{~h}^{-1}$, respectively. The charge/discharge specific capacity of each stage is closely related to the redox reactions of Te. However, because the valence state change behavior of $\mathrm{Te}$ is continuous during the charge/discharge processes, the division of the specific capacities in the above stages does not completely match the valence change behavior of Te [24]. Fig. 5c shows the charge/discharge curves with a current density of $0.2 \mathrm{~A} \mathrm{~g}^{-1}$. The initial discharge specific capacity is $256 \mathrm{~mA} \mathrm{~h} \mathrm{~g}^{-1}$ (the theoretical specific capacity of $\mathrm{Te}-\mathrm{Te}^{2-}$ is $422.1 \mathrm{~mA} \mathrm{~h} \mathrm{~g}^{-1}$ ), and the charge specific capacity is $1152 \mathrm{~mA} \mathrm{~h} \mathrm{~g}^{-1}$ (the theoretical specific capacity of $\mathrm{Te}^{2-}-\mathrm{Te}^{4+}$ is $1266.4 \mathrm{~mA} \mathrm{~h} \mathrm{~g}^{-1}$ ). The actual test capacities are lower than the theoretical specific capacities, which may be due to the chemical dissolution of Te. In addition, many factors need to be controlled to achieve the theoretical specific capacity of the active material in actual experiments, such as current density, battery assembly process, and electrolyte. As shown in Fig. S7, the electrolyte is purple after cycling (Fig. S7a). However, the composite material F- $\mathrm{Ti}_{3} \mathrm{C}_{2} \mathrm{~T}_{x} @ \mathrm{Te}$ can exist in the electrolyte stably (Fig. S7b).

In addition, we performed XPS characterization on $\mathrm{F}-\mathrm{Ti}_{3} \mathrm{C}_{2} \mathrm{~T}_{x} @ \mathrm{Te}$ under different voltage conditions to determine the valence change behavior of Te during charging/discharging. Fig. $5 \mathrm{~d}$ shows the XPS spectrum of Te when fully charged to 2.4 from $1.4 \mathrm{~V}$ (open circuit voltage). The binding energy peaks at 576.5 and $587.2 \mathrm{eV}$ are assigned to $\mathrm{Te} 3 \mathrm{~d}_{3 / 2}$ and $\mathrm{Te} 3 \mathrm{~d}_{5 / 2}$ of $\mathrm{Te}^{4+}$, respectively, indicating that $\mathrm{Te}$ is almost completely oxidized to $\mathrm{Te}^{4+}$ after full charging to $2.4 \mathrm{~V}$. Fig. 5e shows the XPS spectrum of Te when discharged from 2.4 to $1.2 \mathrm{~V}$. The binding energy peaks at 576.5 and $587.2 \mathrm{eV}$ are those of $\mathrm{Te} 3 \mathrm{~d}_{3 / 2}$ and $\mathrm{Te} 3 \mathrm{~d}_{5 / 2}$ of $\mathrm{Te}^{4+}$, respectively, and the binding energy peaks at 573.0 and $583.7 \mathrm{eV}$ are those of $\mathrm{Te} 3 \mathrm{~d}_{3 / 2}$ and $\mathrm{Te} 3 \mathrm{~d}_{5 / 2}$ of Te [58], respectively, indicating that the high-valence $\mathrm{Te}^{4+}$ begins to be reduced to Te during the discharge process. Fig. $5 \mathrm{f}$ is the XPS spectrum of Te when discharged to $0.9 \mathrm{~V}$. The binding energy peaks at 575.3 and $586.2 \mathrm{eV}$ belong to $\mathrm{Te} 3 \mathrm{~d}_{3 / 2}$ and $\mathrm{Te} 3 \mathrm{~d}_{5 / 2}$ of $\mathrm{Te}^{2+}$, respectively, and the peaks at 573.0 and $583.7 \mathrm{eV}$ belong to $\mathrm{Te}$ $3 \mathrm{~d}_{3 / 2}$ and Te $3 \mathrm{~d}_{5 / 2}$ of Te, respectively. As the discharge process progresses, $\mathrm{Te}^{4+}$ is reduced to $\mathrm{Te}^{2+}$ and Te. Fig. $5 \mathrm{~g}$ presents the XPS spectrum of Te when discharged to $0.3 \mathrm{~V}$. The peaks at 575.3 and $586.2 \mathrm{eV}$ belong to $\mathrm{Te} 3 \mathrm{~d}_{3 / 2}$ and $\mathrm{Te} 3 \mathrm{~d}_{5 / 2}$ of $\mathrm{Te}^{2+}$, respectively, and the peaks at 572.4 and $582.7 \mathrm{eV}$ are those of Te $3 \mathrm{~d}_{3 / 2}$ and $\mathrm{Te} 3 \mathrm{~d}_{5 / 2}$ of $\mathrm{Te}^{2-}$, respectively. When the voltage is $0.3 \mathrm{~V}$, $\mathrm{Te}^{4+}$ begins to be reduced to $\mathrm{Te}^{2+}$ and $\mathrm{Te}^{2-}$. Fig. $5 \mathrm{~h}-\mathrm{j}$ shows the valence change behavior of Te during charging. Corresponding to the discharge process, when the battery is charged to $1.1 \mathrm{~V}$, the peaks at 575.3 and $586.2 \mathrm{eV}$ are those of $\mathrm{Te} 3 \mathrm{~d}_{3 / 2}$ and $\mathrm{Te} 3 \mathrm{~d}_{5 / 2}$ of $\mathrm{Te}^{2+}$, respectively, and the peaks at 573.0 and $583.7 \mathrm{eV}$ belong to Te $3 d_{3 / 2}$ and Te $3 d_{5 / 2}$ of Te, respectively. When the battery is charged to 1.5 and $2.2 \mathrm{~V}$, the peaks at 575.3 and $586.2 \mathrm{eV}$ are those of $\mathrm{Te} 3 \mathrm{~d}_{3 / 2}$ and $\mathrm{Te} 3 \mathrm{~d}_{5 / 2}$ of $\mathrm{Te}^{2+}$, respectively, and the peaks at 576.5 and $587.2 \mathrm{eV}$ belong to $\mathrm{Te} 3 \mathrm{~d}_{3 / 2}$ and $\mathrm{Te} 3 \mathrm{~d}_{5 / 2}$ of $\mathrm{Te}^{4+}$, respectively. The specific parameter is shown in Table $\mathrm{S} 3$, and the low-valence $\mathrm{Te}$ ions are oxidized to a high-valence state during the charge process. Consistent with the theoretical cal- 

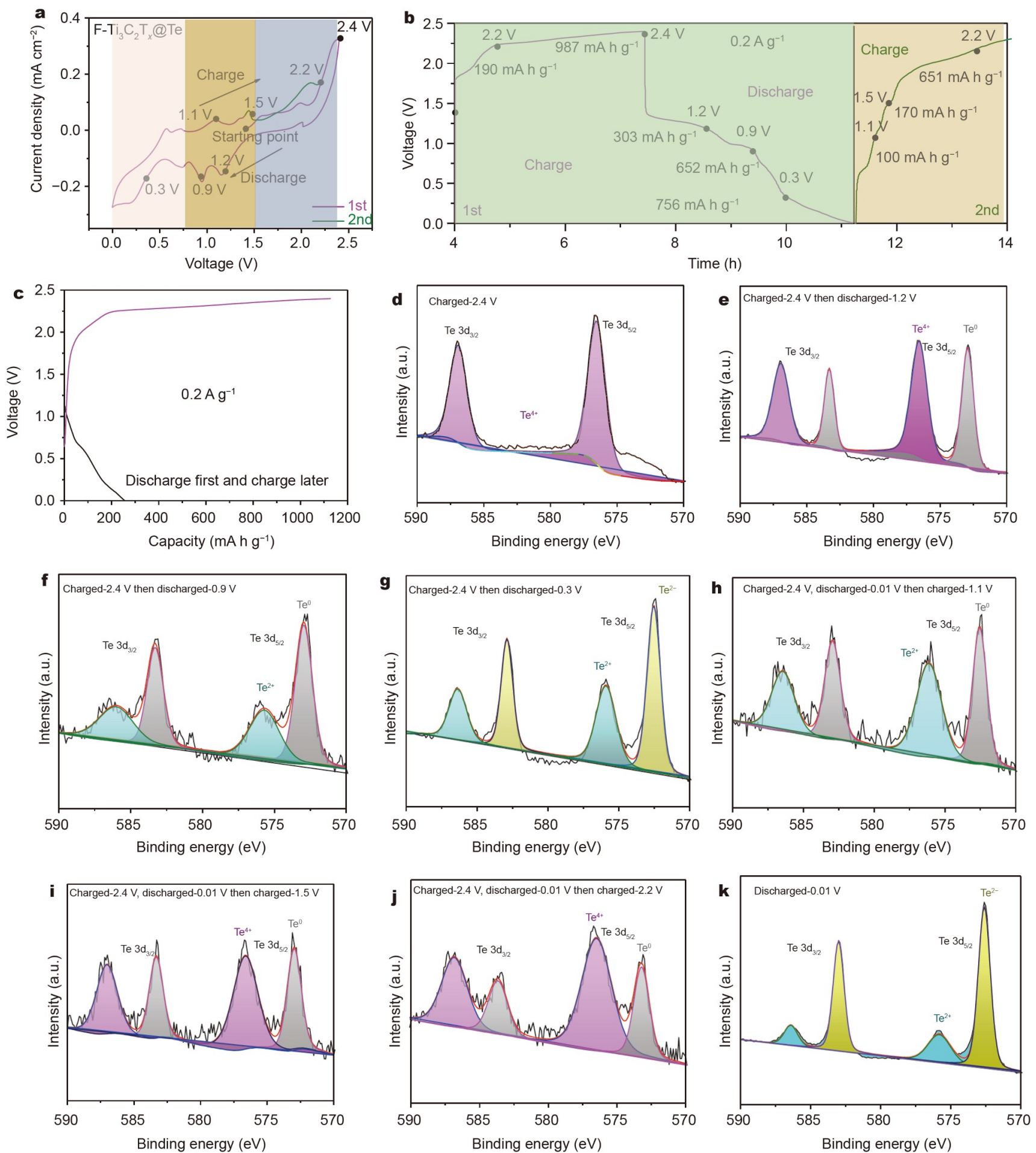

Figure 5 Electrochemical performance of $\mathrm{F}_{-} \mathrm{Ti}_{3} \mathrm{C}_{2} \mathrm{~T}_{x} @ \mathrm{Te}$ in aluminum battery. (a) CV curves, (b) charge/discharge curves, and (c) charge/discharge curve (discharge first). XPS spectra of Te under different voltage conditions: (d) charged to $2.4 \mathrm{~V}$, (e) discharged to $1.2 \mathrm{~V}$, (f) discharged to $0.9 \mathrm{~V}$, (g) discharged to $0.3 \mathrm{~V}$, (h) charged to $1.1 \mathrm{~V}$, (i) charged to $1.5 \mathrm{~V}$, (j) charged to $2.2 \mathrm{~V}$, and $(\mathrm{k})$ discharged to $0.01 \mathrm{~V}$.

culations, the valence change behavior of Te provides capacity for aluminum batteries during charging/discharging. Fig. 5k provides the XPS spectrum of Te when the battery is directly discharged to $0.01 \mathrm{~V}$. The peaks at 572.4 and $582.7 \mathrm{eV}$ are those of Te $3 \mathrm{~d}_{3 / 2}$ and $\mathrm{Te} 3 \mathrm{~d}_{5 / 2}$ of $\mathrm{Te}^{2-}$, respectively, and the peaks at 575.3 and $586.2 \mathrm{eV}$ belong to $\mathrm{Te} 3 \mathrm{~d}_{3 / 2}$ and $\mathrm{Te} 3 \mathrm{~d}_{5 / 2}$ of $\mathrm{Te}^{2+}$ [24], respectively, indicating that $\mathrm{Te}$ can be reduced to $\mathrm{Te}^{2-}$ at a low potential. A small amount of $\mathrm{Te}^{2+}$ may come from the chemical dissolution of $\mathrm{Te}$ in the electrolyte.

The charge/discharge mechanism of the host material F$\mathrm{Ti}_{3} \mathrm{C}_{2} \mathrm{~T}_{x}$ in aluminum batteries was studied by XPS, and the XPS spectra of $\mathrm{Ti} 2 \mathrm{p}, \mathrm{Cl} 2 \mathrm{p}$, and $\mathrm{Al} 2 \mathrm{p}$ under different voltages are shown in Fig. S8. Fig. S8a-d depict the valence change behavior of $\mathrm{Ti}$ ions during charging/discharging. The $\mathrm{Ti}$ ions on the 


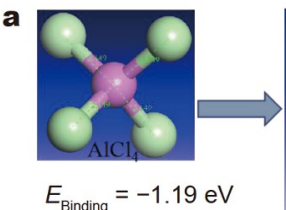

$E_{\text {Binding }}=-1.19 \mathrm{eV}$
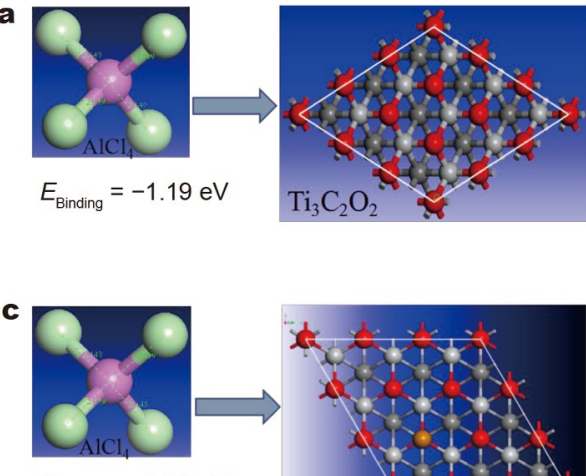

$E_{\text {Binding }}=-2.82 \mathrm{eV}$

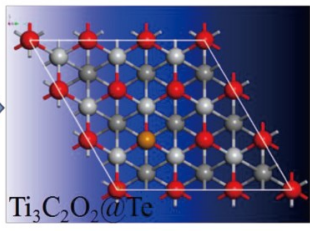

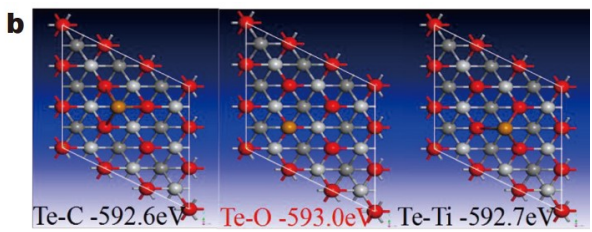

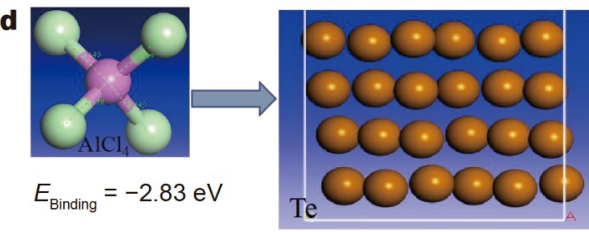

Figure 6 Result of DFT calculations for (a) adsorption of $\left[\mathrm{AlCl}_{4}\right]^{-}$by $\mathrm{Ti}_{3} \mathrm{C}_{2} \mathrm{O}_{2} ;$ (b) models of the interaction of Te and $\mathrm{Ti}_{3} \mathrm{C}_{2} \mathrm{O}_{2}$; (c) adsorption of $\left[\mathrm{AlCl}_{4}\right]^{-}$by $\mathrm{Te} ;(\mathrm{d})$ adsorption of $\left[\mathrm{AlCl}_{4}\right]^{-}$by $\mathrm{Ti}_{3} \mathrm{C}_{2} \mathrm{O}_{2} @ \mathrm{Te}$.

surface of the material are oxidized to a high-valence state $\left(\mathrm{Ti}^{4+}\right)$ during charging, and the high-valence $\mathrm{Ti}$ ions are reduced to a low-valence state $\left(\mathrm{Ti}^{3+}, \mathrm{Ti}^{2+}\right)$ again during the discharge process. The specific data are shown in Table S4. In the aluminum batteries, the percentage of $\mathrm{Ti}^{4+}$ before charging/discharging, fully charged to $2.4 \mathrm{~V}$, and discharged to $0.01 \mathrm{~V}$ is $11.8 \%, 26.9 \%$, and $14.6 \%$, respectively. The valence behavior of Ti-ions provides a certain capacity. Fig. S8e, f depict the XPS spectra of $\mathrm{Al} 2 \mathrm{p}$ and $\mathrm{Cl} 2 \mathrm{p}$ under different voltage conditions. When $\mathrm{F}-\mathrm{Ti}_{3} \mathrm{C}_{2} \mathrm{~T}_{x} @ \mathrm{Te}$ is fully charged to $2.4 \mathrm{~V}$ in an aluminum battery, it shows obvious characteristic peaks of $\mathrm{Cl} 2 \mathrm{p}$ and $\mathrm{Al} 2 \mathrm{p}$. The intensity of the characteristic peak $\mathrm{Cl} 2 \mathrm{p}$ and $\mathrm{Al} 2 \mathrm{p}$ weakens during discharging. $\mathrm{F}-\mathrm{Ti}_{3} \mathrm{C}_{2} \mathrm{~T}_{x} @ \mathrm{Te}$ shows weak characteristic peaks of $\mathrm{Cl} 2 \mathrm{p}$ and Al $2 \mathrm{p}$ when fully discharged to $0.01 \mathrm{~V}$, illustrating that the $\left[\mathrm{AlCl}_{4}\right]^{-}$carrying $\mathrm{Cl}$ is deintercalated from $\mathrm{F}-\mathrm{Ti}_{3} \mathrm{C}_{2} \mathrm{~T}_{x} @ \mathrm{Te}$. This finding is consistent with the valence behavior of $\mathrm{Te}$, and the intercalation/deintercalation of $\left[\mathrm{AlCl}_{4}\right]^{-}$caused the valence behaviors of $\mathrm{Te}$ and $\mathrm{Ti}$ ions. The reaction process is shown in Equations (6 and 7).

Cathode:

$\mathrm{Ti}_{3} \mathrm{C}_{2} \mathrm{~T}_{x}-\mathrm{e}^{-}+\left[\mathrm{AlCl}_{4}\right]^{-} \rightleftharpoons \mathrm{Ti}_{3} \mathrm{C}_{2} \mathrm{~T}_{x}\left[\mathrm{AlCl}_{4}\right]$.

Anode:

$4\left[\mathrm{Al}_{2} \mathrm{Cl}_{7}\right]^{-}+3 \mathrm{e}^{-} \rightleftharpoons \mathrm{Al}+7\left[\mathrm{AlCl}_{4}\right]^{-}$.

DFT calculations were performed to explore the mechanism. First-principles calculations were carried out in the DFT framework, as implemented in the Vienna ab initio simulation package $[59,60]$. The binding energy $\left(E_{\text {binding }}\right)$ was calculated as Equation (8):

$E_{\text {Binding }}=E_{\left(\mathrm{MXene}+\left[\mathrm{AlCl}_{4}\right]^{-}\right.}-\left(E_{\mathrm{MX} \text { ene }}+E_{\left[\mathrm{AlCl}_{4}\right]^{-}}\right)$.

The DFT calculation results are shown in Fig. 6. Fig. 6a shows the adsorption between $\left[\mathrm{AlCl}_{4}\right]^{-}$and $\mathrm{Ti}_{3} \mathrm{C}_{2} \mathrm{O}_{2}$, and the adsorption energy is $-1.19 \mathrm{eV}$. Fig. $6 \mathrm{~b}$ presents the models of the interaction of $\mathrm{Te}$ and $\mathrm{Ti}_{3} \mathrm{C}_{2} \mathrm{~T}_{x}$. Three ways are used to combine Te with $\mathrm{Ti}_{3} \mathrm{C}_{2} \mathrm{~T}_{x}$. When $\mathrm{Te}$ is combined with $\mathrm{C}$ bond, functional group $-\mathrm{OH}$, and $\mathrm{Ti}$ bond, the binding energies are -592.6 , -593.0 , and $-592.7 \mathrm{eV}$, respectively. The calculation shows that $\mathrm{Te}$ is most stable when combined with the functional group -OH. Therefore, the most stable $\mathrm{Ti}_{3} \mathrm{C}_{2} \mathrm{O}_{2} @ \mathrm{Te}$ is used to establish a model to calculate the adsorption energy with $\left[\mathrm{AlCl}_{4}\right]^{-}$. As shown in Fig. $6 c$, the adsorption energy between $\left[\mathrm{AlCl}_{4}\right]^{-}$and
$\mathrm{Ti}_{3} \mathrm{C}_{2} \mathrm{O}_{2} @ \mathrm{Te}$ is $-2.82 \mathrm{eV}$, which indicates that $\mathrm{Ti}_{3} \mathrm{C}_{2} \mathrm{O}_{2} @ \mathrm{Te}$ is more inclined to adsorb $\left[\mathrm{AlCl}_{4}\right]^{-}$than $\mathrm{Ti}_{3} \mathrm{C}_{2} \mathrm{O}_{2}$. Fig. 6d shows the adsorption between $\left[\mathrm{AlCl}_{4}\right]^{-}$and $\mathrm{Te}$, and the adsorption energy is $-2.83 \mathrm{eV}$. Although $\mathrm{Te}$ can also adsorb $\left[\mathrm{AlCl}_{4}\right]^{-}$stably, the electrochemical performance is poor in the absence of $\mathrm{F}_{-}-\mathrm{Ti}_{3} \mathrm{C}_{2} \mathrm{~T}_{x}$ (Fig. S6).

\section{CONCLUSIONS}

In summary, the electrochemical performance of the aluminum battery with MXenes as the support material was studied. The battery shows excellent electrochemical performance, and it has an initial charge specific capacity of $987 \mathrm{~mA} \mathrm{~h}^{-1}$ at $0.2 \mathrm{Ag}^{-1}$ and a discharge specific capacity of $1096 \mathrm{~mA} \mathrm{~h} \mathrm{~g}^{-1}$ with an obvious discharge platform around $1.3 \mathrm{~V}$. The specific capacity is $449 \mathrm{~mA} \mathrm{~h} \mathrm{~g}^{-1}$ after 150 cycles with a current density of $0.6 \mathrm{~A} \mathrm{~g}^{-1}$, and the capacity retention rate is about $70 \%$. Furthermore, the valence behaviors of $\mathrm{Te}$ and $\mathrm{Ti}$ ions were studied. $\mathrm{Te}$ and $\mathrm{Ti}$ ions $\left(\mathrm{Ti}^{3+}, \mathrm{Ti}^{2+}\right)$ are oxidized to $\mathrm{Te}^{4+}$ and $\mathrm{Ti}^{4+}$ when the battery is fully charged to $2.4 \mathrm{~V}$, and the high-valence $\mathrm{Te}^{4+}$ and $\mathrm{Ti}^{4+}$ are restored to $\mathrm{Te}$ and $\mathrm{Ti}$ ions $\left(\mathrm{Ti}^{3+}, \mathrm{Ti}^{2+}\right)$ during discharging. Te is reduced to lower-valence $\mathrm{Te}^{2-}$ when the discharge voltage is lower than $0.6 \mathrm{~V}$ in the aluminum battery. In addition, the $\left[\mathrm{AlCl}_{4}\right]^{-}$intercalation/deintercalation into $\mathrm{F}-\mathrm{Ti}_{3} \mathrm{C}_{2} \mathrm{~T}_{x} @ \mathrm{Te}$ is proved, and the intercalation/deintercalation of $\left[\mathrm{AlCl}_{4}\right]^{-}$causes the valence behaviors of $\mathrm{Te}$ and $\mathrm{Ti}$ ions.

Aluminum batteries with a higher specific capacity are expected to be prepared due to the multivalence state of Te. However, some challenges in preparing aluminum batteries remain due to the strongly acidity of the electrolyte and the metal properties of Te. First, the electrolyte of the aluminum battery should be improved to reduce the chemical dissolution of Te. Second, the electrode material and separator should be further modified to suppress the shuttle effect of Te. Considering their outstanding advantages of safety and low price, rechargeable aqueous aluminum batteries are also an important research direction $[61,62]$.

\section{Received 15 March 2021; accepted 17 May 2021;} published online 9 July 2021

1 Manthiram A, Fu Y, Chung SH, et al. Rechargeable lithium-sulfur batteries. Chem Rev, 2014, 114: 11751-11787

2 Canepa P, Sai Gautam G, Hannah DC, et al. Odyssey of multivalent cathode materials: Open questions and future challenges. Chem Rev, 


\section{7, 117: 4287-4341}

3 Chen $\mathrm{H}, \mathrm{Xu} \mathrm{H}$, Zheng B, et al. Oxide film efficiently suppresses dendrite growth in aluminum-ion battery. ACS Appl Mater Interfaces, 2017, 9: 22628-22634

4 Lin MC, Gong M, Lu B, et al. An ultrafast rechargeable aluminium-ion battery. Nature, 2015, 520: 324-328

5 Zhang $\mathrm{X}$, Tang $\mathrm{Y}$, Zhang $\mathrm{F}$, et al. A novel aluminum-graphite dual-ion battery. Adv Energy Mater, 2016, 6: 1502588

6 Wang DY, Wei CY, Lin MC, et al. Advanced rechargeable aluminium ion battery with a high-quality natural graphite cathode. Nat Commun, 2017, 8: 14283

7 Chen H, Guo F, Liu Y, et al. A defect-free principle for advanced graphene cathode of aluminum-ion battery. Adv Mater, 2017, 29: 1605958

8 Chen $\mathrm{H}$, Chen $\mathrm{C}$, Liu $\mathrm{Y}$, et al. High-quality graphene microflower design for high-performance Li-S and Al-ion batteries. Adv Energy Mater, 2017, 7: 1700051

9 Wang W, Jiang B, Xiong W, et al. A new cathode material for supervalent battery based on aluminium ion intercalation and deintercalation. Sci Rep, 2013, 3: 3383

10 Jayaprakash N, Das SK, Archer LA. The rechargeable aluminum-ion battery. Chem Commun, 2011, 47: 12610-12612

$11 \mathrm{Tu}$ J, Lei $\mathrm{H}, \mathrm{Yu} \mathrm{Z}$, et al. Ordered $\mathrm{WO}_{3-x}$ nanorods: facile synthesis and their electrochemical properties for aluminum-ion batteries. Chem Commun, 2018, 54: 1343-1346

12 Liu J, Li Z, Huo X, et al. Nanosphere-rod-like $\mathrm{Co}_{3} \mathrm{O}_{4}$ as high performance cathode material for aluminium ion batteries. J Power Sources, 2019, 422: 49-56

13 Zhu N, Wu F, Wang Z, et al. Reversible $\mathrm{Al}^{3+}$ storage mechanism in anatase $\mathrm{TiO}_{2}$ cathode material for ionic liquid electrolyte-based aluminum-ion batteries. J Energy Chem, 2020, 51: 72-80

$14 \mathrm{Hu} \mathrm{Z}$, Guo $\mathrm{Y}$, Jin $\mathrm{H}$, et al. A rechargeable aqueous aluminum-sulfur battery through acid activation in water-in-salt electrolyte. Chem Commun, 2020, 56: 2023-2026

$15 \mathrm{Hu}$ Y, Luo B, Ye D, et al. An innovative freeze-dried reduced graphene oxide supported $\mathrm{SnS}_{2}$ cathode active material for aluminum-ion batteries. Adv Mater, 2017, 29: 1606132

16 Wang S, Jiao S, Wang J, et al. High-performance aluminum-ion battery with CuS@C microsphere composite cathode. ACS Nano, 2017, 11: 469-477

17 Li Z, Niu B, Liu J, et al. Rechargeable aluminum-ion battery based on $\mathrm{MoS}_{2}$ microsphere cathode. ACS Appl Mater Interfaces, 2018, 10: 9451-9459

18 Cai T, Zhao L, Hu H, et al. Stable $\mathrm{CoSe}_{2} /$ carbon nanodice@reduced graphene oxide composites for high-performance rechargeable aluminum-ion batteries. Energy Environ Sci, 2018, 11: 2341-2347

19 Yang H, Wu F, Bai Y, et al. Toward better electrode/electrolyte interfaces in the ionic-liquid-based rechargeable aluminum batteries. J Energy Chem, 2020, 45: 98-102

20 Gao T, Li X, Wang X, et al. A rechargeable Al/S battery with an ionicliquid electrolyte. Angew Chem Int Ed, 2016, 55: 9898-9901

21 Yu X, Manthiram A. Electrochemical energy storage with a reversible nonaqueous room-temperature aluminum-sulfur chemistry. Adv Energy Mater, 2017, 7: 1700561

22 Huang X, Liu Y, Liu C, et al. Rechargeable aluminum-selenium batteries with high capacity. Chem Sci, 2018, 9: 5178-5182

23 Li Z, Wang X, Li X, et al. Reduced graphene oxide ( $\mathrm{rGO}$ ) coated porous nanosphere $\mathrm{TiO}_{2} @ S e$ composite as cathode material for high-performance reversible Al-Se batteries. Chem Eng J, 2020, 400: 126000

24 Jiao H, Tian D, Li S, et al. A rechargeable Al-Te battery. ACS Appl Energy Mater, 2018, 1: 4924-4930

25 Zhang X, Jiao S, Tu J, et al. Rechargeable ultrahigh-capacity telluriumaluminum batteries. Energy Environ Sci, 2019, 12: 1918-1927

26 Naguib M, Kurtoglu M, Presser V, et al. Two-dimensional nanocrystals: Two-dimensional nanocrystals produced by exfoliation of $\mathrm{Ti}_{3} \mathrm{AlC}_{2}$. Adv Mater, 2011, 23: 4207

27 Naguib M, Mashtalir O, Carle J, et al. Two-dimensional transition metal carbides. ACS Nano, 2012, 6: 1322-1331
28 Naguib M, Gogotsi Y. Synthesis of two-dimensional materials by selective extraction. Acc Chem Res, 2015, 48: 128-135

29 Wang $\mathrm{H}, \mathrm{Wu} \mathrm{Y}$, Yuan X, et al. Clay-inspired MXene-based electrochemical devices and photo-electrocatalyst: State-of-the-art progresses and challenges. Adv Mater, 2018, 30: 1704561

30 Nan J, Guo X, Xiao J, et al. Nanoengineering of 2D MXene-based materials for energy storage applications. Small, 2021, 17: 1902085

31 Lukatskaya MR, Mashtalir O, Ren CE, et al. Cation intercalation and high volumetric capacitance of two-dimensional titanium carbide. Science, 2013, 341: 1502-1505

32 Ghidiu M, Lukatskaya MR, Zhao MQ, et al. Conductive two-dimensional titanium carbide 'clay' with high volumetric capacitance. Nature, 2014, 516: 78-81

33 Yu L, Fan Z, Shao Y, et al. Versatile N-doped MXene ink for printed electrochemical energy storage application. Adv Energy Mater, 2019, 9: 1901839

34 Wang $\mathrm{C}$, Xie $\mathrm{H}$, Chen $\mathrm{S}$, et al. Atomic cobalt covalently engineered interlayers for superior lithium-ion storage. Adv Mater, 2018, 30: 1802525

35 Ahmed B, Anjum DH, Gogotsi Y, et al. Atomic layer deposition of $\mathrm{SnO}_{2}$ on MXene for Li-ion battery anodes. Nano Energy, 2017, 34: 249256

36 Zhao S, Meng X, Zhu K, et al. Li-ion uptake and increase in interlayer spacing of $\mathrm{Nb}_{4} \mathrm{C}_{3}$ MXene. Energy Storage Mater, 2017, 8: 42-48

37 Zhang $\mathrm{F}$, Guo X, Xiong $\mathrm{P}$, et al. Interface engineering of MXene composite separator for high-performance $\mathrm{Li}-\mathrm{Se}$ and $\mathrm{Na}-\mathrm{Se}$ batteries. Adv Energy Mater, 2020, 10: 2000446

38 Guo X, Xie X, Choi S, et al. $\mathrm{Sb}_{2} \mathrm{O}_{3} / \mathrm{MXene}\left(\mathrm{Ti}_{3} \mathrm{C}_{2} \mathrm{~T}_{x}\right)$ hybrid anode materials with enhanced performance for sodium-ion batteries. J Mater Chem A, 2017, 5: 12445-12452

39 Zhao MQ, Xie X, Ren CE, et al. Hollow MXene spheres and 3D macroporous MXene frameworks for Na-ion storage. Adv Mater, 2017, 29: 1702410

40 Lian P, Dong Y, Wu ZS, et al. Alkalized $\mathrm{Ti}_{3} \mathrm{C}_{2}$ MXene nanoribbons with expanded interlayer spacing for high-capacity sodium and potassium ion batteries. Nano Energy, 2017, 40: 1-8

41 Guo X, Zhang W, Zhang J, et al. Boosting sodium storage in twodimensional phosphorene/ $\mathrm{Ti}_{3} \mathrm{C}_{2} \mathrm{~T}_{x}$ MXene nanoarchitectures with stable fluorinated interphase. ACS Nano, 2020, 14: 3651-3659

$42 \mathrm{Xu} \mathrm{M}$, Lei S, Qi J, et al. Opening magnesium storage capability of twodimensional MXene by intercalation of cationic surfactant. ACS Nano, 2018, 12: 3733-3740

43 Zhao MQ, Ren CE, Alhabeb M, et al. Magnesium-ion storage capability of MXenes. ACS Appl Energy Mater, 2019, 2: 1572-1578

44 Liang X, Rangom Y, Kwok CY, et al. Interwoven MXene nanosheet/ carbon-nanotube composites as Li-S cathode hosts. Adv Mater, 2017, 29: 1603040

45 Wang $\mathrm{D}$, Li F, Lian $\mathrm{R}$, et al. A general atomic surface modification strategy for improving anchoring and electrocatalysis behavior of $\mathrm{Ti}_{3} \mathrm{C}_{2} \mathrm{~T}_{2}$ MXene in lithium-sulfur batteries. ACS Nano, 2019, 13: $11078-11086$

46 Huang Z, Liu B, Liu J. $\mathrm{Mn}^{2+}$-assisted DNA oligonucleotide adsorption on $\mathrm{Ti}_{2} \mathrm{C}$ MXene nanosheets. Langmuir, 2019, 35: 9858-9866

47 VahidMohammadi A, Hadjikhani A, Shahbazmohamadi S, et al. Twodimensional vanadium carbide (MXene) as a high-capacity cathode material for rechargeable aluminum batteries. ACS Nano, 2017, 11: $11135-11144$

48 Huo $\mathrm{X}$, Wang $\mathrm{X}, \mathrm{Li} \mathrm{Z}$, et al. Two-dimensional composite of $\mathrm{D}$ $\mathrm{Ti}_{3} \mathrm{C}_{2} \mathrm{~T}_{x} @ \mathrm{~S} @ \mathrm{TiO}_{2}$ (MXene) as the cathode material for aluminum-ion batteries. Nanoscale, 2020, 12: 3387-3399

49 Li Z, Wang XX, Zhang W, et al. Two-dimensional $\mathrm{Ti}_{3} \mathrm{C}_{2} @ \mathrm{CTAB}-\mathrm{Se}$ (MXene) composite cathode material for high-performance rechargeable aluminum batteries. Chem Eng J, 2020, 398: 125679

50 Huo X, Zhang B, Li J, et al. Two-dimensional F- $\mathrm{Ti}_{3} \mathrm{C}_{2} \mathrm{~T}_{x} @ \mathrm{Ag}$ composite for an extraordinary long cycle lifetime with high specific capacity in an aluminum battery. ACS Appl Mater Interfaces, 2021, 13: 11822-11832

51 Alhabeb M, Maleski K, Anasori B, et al. Guidelines for synthesis and processing of two-dimensional titanium carbide $\left(\mathrm{Ti}_{3} \mathrm{C}_{2} \mathrm{~T}_{x}\right.$ MXene). 
Chem Mater, 2017, 29: 7633-7644

52 Luo J, Zhang W, Yuan H, et al. Pillared structure design of MXene with ultralarge interlayer spacing for high-performance lithium-ion capacitors. ACS Nano, 2017, 11: 2459-2469

53 Liang X, Garsuch A, Nazar LF. Sulfur cathodes based on conductive MXene nanosheets for high-performance lithium-sulfur batteries. Angew Chem Int Ed, 2015, 54: 3907-3911

54 Xu S, Wei G, Li J, et al. Binder-free $\mathrm{Ti}_{3} \mathrm{C}_{2} \mathrm{~T}_{x}$ MXene electrode film for supercapacitor produced by electrophoretic deposition method. Chem Eng J, 2017, 317: 1026-1036

55 Huo X, Liu Y, Li R, et al. Two-dimensional $\mathrm{Ti}_{3} \mathrm{C}_{2} \mathrm{~T}_{x} @ \mathrm{~S}$ as cathode for room temperature sodium-sulfur batteries. Ionics, 2019, 25: 5373-5382

56 Nayak P, Jiang Q, Mohanraman R, et al. Inherent electrochemistry and charge transfer properties of few-layered two-dimensional $\mathrm{Ti}_{3} \mathrm{C}_{2} \mathrm{~T}_{x}$ MXene. Nanoscale, 2018, 10: 17030-17037

57 Zhang X, Wang M, Tu J, et al. Hierarchical N-doped porous carbon hosts for stabilizing tellurium in promoting $\mathrm{Al}-\mathrm{Te}$ batteries. J Energy Chem, 2021, 57: 378-385

58 Bahl MK, Watson RL, Irgolic KJ. X-ray photoemission studies of tellurium and some of its compounds. J Chem Phys, 1977, 66: 5526-5535

59 Kresse G, Furthmüller J. Efficient iterative schemes for ab initio totalenergy calculations using a plane-wave basis set. Phys Rev B, 1996, 54: $11169-11186$

60 Wang X, Wang C, Ci S, et al. Accelerating 2D MXene catalyst discovery for the hydrogen evolution reaction by computer-driven workflow and an ensemble learning strategy. J Mater Chem A, 2020, 8: 23488-23497

61 Wu C, Gu S, Zhang Q, et al. Electrochemically activated spinel manganese oxide for rechargeable aqueous aluminum battery. Nat Commun, 2019, 10: 73

62 Gao Y, Yang H, Wang X, et al. The compensation effect mechanism of $\mathrm{Fe}-\mathrm{Ni}$ mixed Prussian blue analogues in aqueous rechargeable aluminum-ion batteries. ChemSusChem, 2020, 13: 732-740

Acknowledgements This work was financially supported by the National Natural Science Foundation of China (51772025 and 51972023).

Author contributions Huo X and Li J conceived the idea, designed the research, conducted the experiment, analyzed the data and wrote the manuscript. Wang $\mathrm{X}$ analyzed the data. Huo $\mathrm{X}$ and Li J revised the manuscript. All authors contributed to the general discussion.

Conflict of interest The authors declare no conflict of interest.

Supplementary information Experimental details and supporting data are available in the online version of the paper.

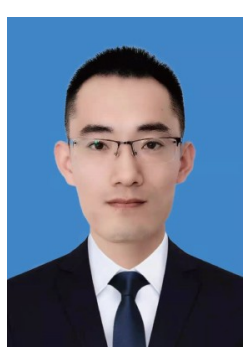

Xiaogeng Huo received his $\mathrm{PhD}$ in 2021 from the University of Science and Technology Beijing. His research direction is energy materials, mainly focusing on the application of $2 \mathrm{D}$ materials, such as MXenes, in secondary batteries.

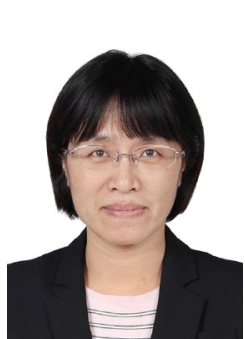

Jianling $\mathbf{~} \mathbf{i}$ is a Professor at the School of Metallurgical and Ecological Engineering, University of Science and Technology Beijing. She graduated from Harbin Institute of Technology with a bachelor's degree in 1993 and a $\mathrm{PhD}$ in 1998. She worked as a postdoctoral fellow at Tsinghua University from 1999 to 2001. Currently, her main research is focused on energy storage materials, including Al-ion battery, Li/ $\mathrm{Na}$-ion battery and supercapacitors.

\section{MXenes@Te作为高性能铝电池复合正极材料}

霍晓更 ${ }^{1}$, 王晓旭 ${ }^{2}$, 李建玲 $1^{*}$, 张宝 ${ }^{1}$, 章羽 ${ }^{1}$, 秦特 ${ }^{1}$, 康飞宇 ${ }^{3}$

摘要 新兴的二维材料MXenes在储能领域中发挥着重要作用, 并展现 了优异的电化学性能. 本文中我们制备了二维层状MXenes $\left(\mathrm{F}-\mathrm{Ti}_{3} \mathrm{C}_{2} \mathrm{~T}_{x}\right)$, 通过高温蒸镀法将 $\mathrm{Te}$ 单质负载在 $\mathrm{F}-\mathrm{Ti}_{3} \mathrm{C}_{2} \mathrm{~T}_{x}$ 的表面, 以MXenes@Te作为 铝电池正极, 其首次充/放电比容量为 $987 / 1096 \mathrm{~mA} \mathrm{~h} \mathrm{~g}^{-1}$. 在不同电流密 度条件下, 铝电池的放电电压平台稳定在 $1.3 \mathrm{~V}$ 左右, 当以 MXenes@ $\mathrm{Te}$ 为活性材料计算时, 铝电池的比容量为 $258 \mathrm{~mA} \mathrm{~h} \mathrm{~g}^{-1}$, 这得益于MXenes 材料优异的电导率及其二维层状结构. 通过密度泛函理论探索了其机 理, 计算结果表明, $\mathrm{Ti}_{3} \mathrm{C}_{2} \mathrm{O}_{2} @ \mathrm{Te}$ 比 $\mathrm{Ti}_{3} \mathrm{C}_{2} \mathrm{O}_{2}$ 更倾向于吸附 $\left[\mathrm{AlCl}_{4}\right]^{-}$. 此外, 通过热力学计算(Factsage7.1)和X射线光电子能谱研究了元素 $\mathrm{Te}$ 的价态 变化. 研究结果表明, 当铝电池充满至 $2.4 \mathrm{~V}$ 时, 单质 $\mathrm{Te}$ 和 $\mathrm{Ti}$ 离子 $\left(\mathrm{Ti}^{3+}\right.$, $\left.\mathrm{Ti}^{2+}\right)$ 被氧化为 $\mathrm{Te}^{4+}$ 和 $\mathrm{Ti}^{4+}$. 在放电过程中, 高价态的 $\mathrm{Te}^{4+}$ 和 $\mathrm{Ti}^{4+}$ 被重新还 原为单质 $\mathrm{Te}$ 和 $\mathrm{Ti}$ 离子 $\left(\mathrm{Ti}^{3+}, \mathrm{Ti}^{2+}\right)$. 当放电电压低于 $0.6 \mathrm{~V}$ 时, 单质 $\mathrm{Te}$ 被还 原为更低价态的 $\mathrm{Te}^{2-}$, 而要将单质 $\mathrm{Te}$ 氧化为 $\mathrm{Te}^{6+}$, 则需要更高的充电电 压 $(2.56 \mathrm{~V})$. 